\title{
CORRELATES OF SNAIL SHELL VARIATION ALONG A UNIDIRECTIONAL FRESHWATER GRADIENT IN LITHASIA GENICULATA (HALDEMAN, 1840) (CAENOGASTROPODA: PLEUROCERIDAE) FROM THE DUCK RIVER, TENNESSEE, USA
}

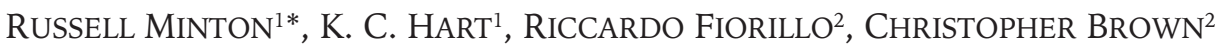 \\ ${ }^{1}$ Department of Biological and Environmental Sciences, University of Houston Clear Lake, 2700 Bay Area \\ Boulevard MC 39, Houston, Texas 77058 USA (e-mail: mintonrl@gmail.com; hartk0708@uhcl.edu) \\ ${ }^{2}$ School of Science and Technology, Georgia Gwinnett College, 1000 University Center Lane, \\ Lawrenceville, Georgia 30043 USA (e-mail: rfiorill@ggc.edu; cbrown37@ggc.edu) \\ *corresponding author
}

ABSTRACT: Phenotypic plasticity in snail shells is a well-documented phenomenon, specifically in freshwater species. In riverine taxa, shells respond to the unidirectional gradient of flow and depth as well as to predation by crushing predators. Using populations of Lithasia geniculata from the Duck River, Tennessee, USA, we examined environmental correlates of shell shape change and resistance to crushing along a riverine gradient. Shells were more globose, more robust, and more resistant to crushing forces downstream relative to upstream; these characteristics were correlated with river discharge and presence of molluscivorous fish. Size, however, did not have effects on shape nor crushing strength. These data are consistent with those observed in other snail species, and expand on our knowledge of potential fitness benefits and causes of plasticity in freshwater snail shells.

KEY WORDS: river discharge, geometric morphometrics, phenotypic plasticity, crushing resistance, morphology

\section{INTRODUCTION}

Phenotypic variation in snail shell morphology is a generalised phenomenon observed in many species (TRUSSELl 2000, KISTNER \& DYBDAHL 2013). For example, in marine snails the presence of predators induces thicker and more sculptured shells (APPLETON \& PALMER 1988), while size and shape vary with wave exposure (BROWN \& QUINN 1988, ETTER 1988). Similar patterns are observed in freshwater snails. For example, snails exposed to shell-entering predators including crayfish will produce narrow shells with narrow apertures (ALEXANDER \& COVICH 1991), decreasing the ability of the predator to access the animal inside. Conversely, snails exposed to whole-animal predators like fish produce globose, sculptured shells that increase handling time by the predator and are more resistant to crushing by the fishes' pharyngeal jaws (DEWITT et al. 2000, RASSER \& CoviCH 2014). Freshwater snails may also modify their shells in response to the hydrodynamic forces of the system they are in. Shells may be narrower in shallower headwaters to provide less drag in variable flow conditions (HURYN \& DENNY 1997), and more globose in deeper and faster-flowing stretches to protect against non-predatory impact and provide greater surface area for foot adhesion (DUSSART 1987, HAASE 2003).

One group exhibiting high amounts of shell variation is Pleuroceridae, the second largest family of 
freshwater snails in North America (JOHNSON et al. 2013). TRYON (1873) highlighted the variability inherent in pleurocerid shells, and ADAMS (1915), GOODRICH (1937), and MiNTON et al. (2011) showed that shell shape changes in a downstream fashion in Io, Pleurocera, and Elimia respectively. We aimed to further explore the nature of pleurocerid shell variation by expanding on work done previously in Lithasia. The genus Lithasia comprises nine species, many of which exhibit variable and plastic shell morphologies (JOHNSON et al. 2013). One species, Lithasia geniculata (Haldeman, 1840) from the Duck River in Tennessee, exhibits shell plasticity in an upstream-downstream fashion. Multiple authors have confirmed that L. geniculata has four diagnosable shell forms; once treated as nominal species, they represent one taxon exhibiting continuous variation throughout the river (DAVIS 1974, STEIN \& STANSBERY 1984, MinTON \& LYDEARD 2003, MinTON et al. 2008). The smooth more globose-shelled L. geniculata form pinguis occupies the headwaters and is replaced by the more conical duttoniana and fuliginosa forms mid-river. Both forms then transition to the heavily sculptured and globose geniculata form downstream to the mouth (Fig. 1). STEIN \& STANSBERY (1984) additionally showed gene flow between populations in the river, suggesting L. geniculata may exhibit polyphenic variation (STEARNS 1989).

Minton et al. (2008) were the first to quantify shell shape plasticity in Duck River L. geniculata. They showed that shells displayed continuous variation from upstream to downstream, becoming more globose and obese in lower reaches. The authors proposed that the increased globosity and shell inflation was related to predation pressure and discharge, but did not test either factor. Our aim then was to correlate shell shape and crushing resistance to river discharge, predator presence, and shell size and mass. Our hope was to identify correlates which would describe and explain the observed shell variation along a riverine, unidirectional environmental gradient. Consistent patterns of shell variation should persist and evolve if four criteria are met: spatial environmental heterogeneity; reliable environmental inducing cues; fitness benefits that outweigh the fitness costs of producing the variation; and a genetic basis for the variation (TOLLRIAN \& HARVELL 1999, BERRIGAN \& SCHEINER 2004). Duck River L. geniculata provided us with a model system for examining all four factors applied to freshwater snail shell variation. The Duck River provides directional environmental heterogeneity that generally follows river continuum theory (VANNOTE et al. 1980). This unidirectional gradient is consistent over time (USGS 2017), and as such should provide reliable environmental cues to organisms exposed to it. Previous research showed that pleurocerid shell variation has both genetic and environmental components (DILLON 1984, WHELAN et al. 2012). Lastly, our measures of crushing resistance could serve as surrogates of fitness benefits; snail shells that are more globose and have greater masses are predicted to be more crush resistant and less susceptible to predatory and non-predatory damage (OSENBERG \& MitTelbach 1989, Dillon 2000).

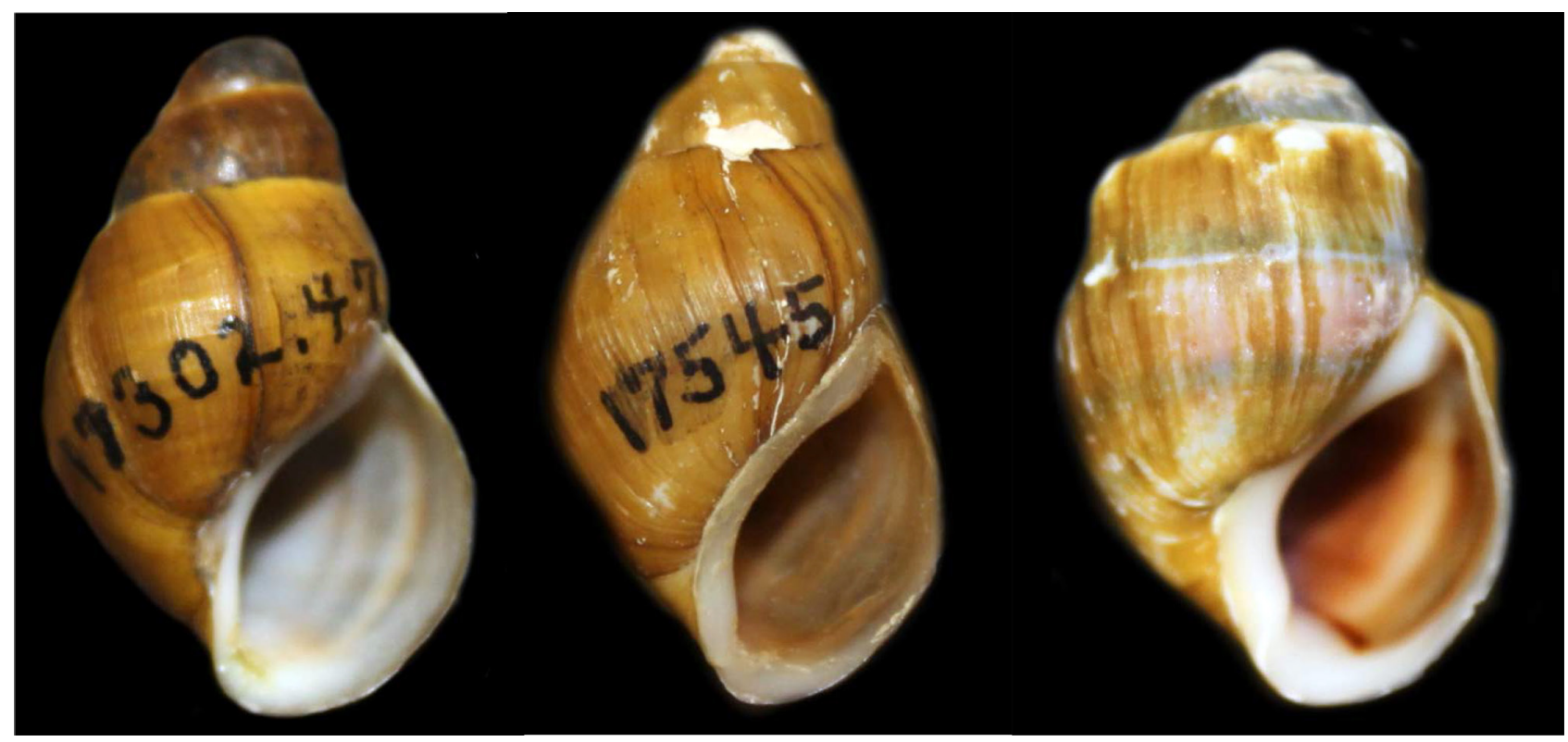

Fig. 1. Representative L. geniculata shells from the Duck River, Tennessee. Left to right: L. geniculata form pinguis, form fuliginosa, and form geniculata 


\section{MATERIAL AND METHODS}

We randomly selected 20 undamaged dry shells from each of 15 populations of $L$. geniculata collected at various points in the Duck River (Fig. 2, Table 1). No collection methods nor environmental data accompanied every specimen, however some specimens were those collected by STEIN \& STANSBERY (1984). They reported that snails "were collected by hand picking from cobbles, boulders, bedrock ledges, and occasionally from mud substrates in water less than three feet deep, generally in moderate to swift water" (STEIN \& STANSBERY 1984: 6). We recorded the river mile where shells were collected, and the mass of each shell to the nearest $0.01 \mathrm{~g}$. Both duttoniana and fuliginosa morphotypes were present in the collection from river mile 186.5, so we used 20 of each form. Although the shells we used were collected in the 1980s, there was insufficient data from those decades available to calculate the relationship of discharge volume to river mileage. Therefore, we used discharge volumes from six United States Geological Survey gauging stations along the Duck River (USGS 2017). We calculated the mean annual discharge at each station for the interval 2010 to 2016, and regressed it against river mileage. Since the relationship was significant and strongly correlated $\left(\mathrm{R}^{2}=0.99, \mathrm{p}<0.05\right.$; data not shown), we used the regression formula to estimate the amount of discharge at each of the snail collection sites (Table 2). While the absolute discharge volumes may not be identical to those experienced by the snails we used, the trends should be consistent.

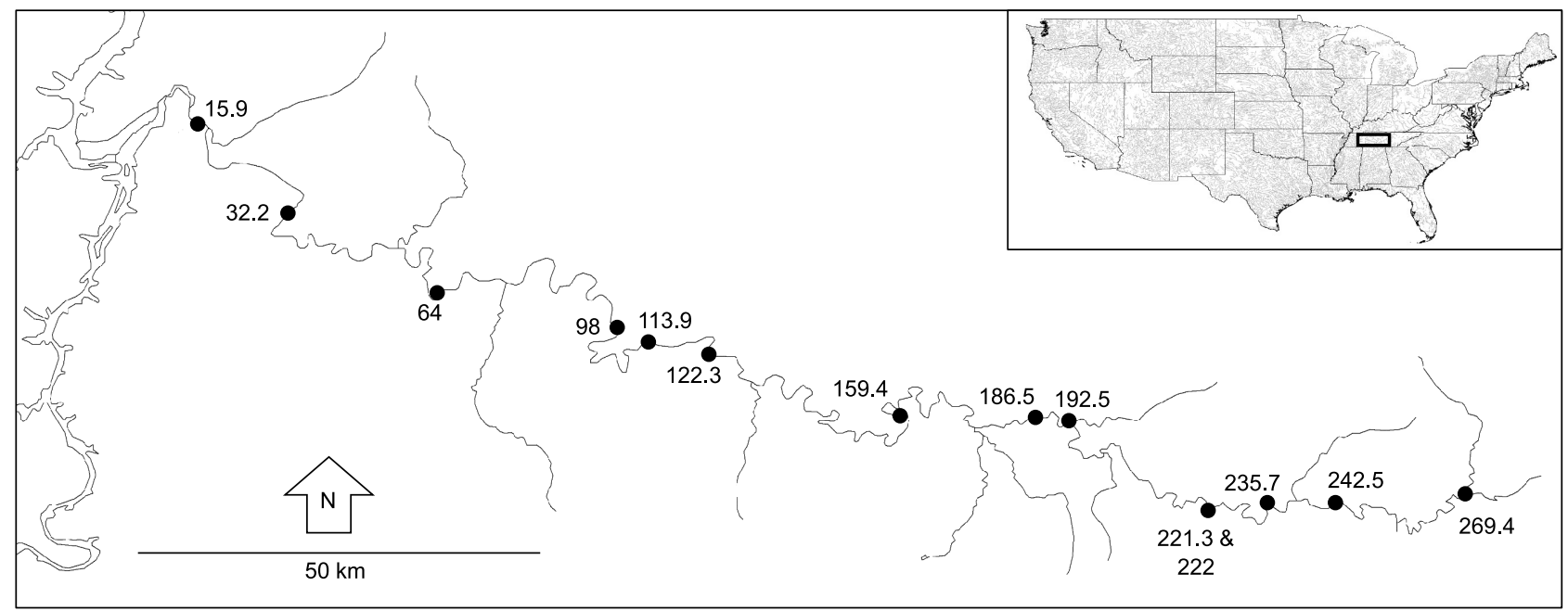

Fig. 2. Map of the Duck River showing the collection sites of the snails used. Approximate position of Only and Normandy Dam are shown by dotted lines delineating the lower, middle, and upper river designations used for fish predator assignment

Table 1. Summarised data for the fifteen populations of L. geniculata used in the study. Lot refers to Ohio State University Museum of Zoology accession number

\begin{tabular}{rlcccc}
\hline \multicolumn{1}{c}{ Lot } & Morphotype & River mile & Centroid size & Mass $(\mathrm{g})$ & Force $(\mathrm{N})$ \\
\hline 17595 & geniculata & 15.9 & $782.61 \pm 54.96$ & $2.94 \pm 0.68$ & $129.93 \pm 61.38$ \\
17309 & geniculata & 32.2 & $925.36 \pm 58.64$ & $2.14 \pm 0.49$ & $191.71 \pm 71.97$ \\
1630 & geniculata & 64.0 & $913.97 \pm 89.25$ & $2.07 \pm 0.61$ & $90.77 \pm 37.11$ \\
1649 & fuliginosa & 98.0 & $623.78 \pm 57.62$ & $1.40 \pm 0.37$ & $82.16 \pm 41.91$ \\
17545 & fuliginosa & 113.9 & $604.67 \pm 30.15$ & $1.29 \pm 0.22$ & $91.72 \pm 39.27$ \\
711 & fuliginosa & 122.3 & $715.39 \pm 40.32$ & $1.71 \pm 0.35$ & $74.84 \pm 26.27$ \\
692 & fuliginosa & 159.4 & $831.20 \pm 62.64$ & $2.07 \pm 0.60$ & $136.00 \pm 57.51$ \\
16460 & duttoniana & 159.4 & $963.13 \pm 325.53$ & $1.16 \pm 0.29$ & $61.71 \pm 29.32$ \\
1670 & duttoniana & 186.5 & $877.02 \pm 70.50$ & $1.55 \pm 0.40$ & $77.31 \pm 27.06$ \\
16543 & fuliginosa & 192.5 & $813.65 \pm 55.87$ & $0.83 \pm 0.19$ & $56.39 \pm 20.76$ \\
16044 & fuliginosa & 221.3 & $745.47 \pm 50.36$ & $1.06 \pm 0.24$ & $52.05 \pm 24.78$ \\
8510 & fuliginosa & 222.0 & $826.12 \pm 118.47$ & $0.96 \pm 0.17$ & $42.53 \pm 19.38$ \\
13839 & fuliginosa & 235.7 & $956.38 \pm 53.85$ & $1.68 \pm 0.26$ & $55.23 \pm 27.69$ \\
17301 & fuliginosa & 242.5 & $679.67 \pm 42.190$ & $1.44 \pm 0.32$ & $58.92 \pm 27.41$ \\
17302 & pinguis & 269.4 & $759.49 \pm 46.490$ & $0.82 \pm 0.18$ & $57.26 \pm 14.66$ \\
\hline
\end{tabular}




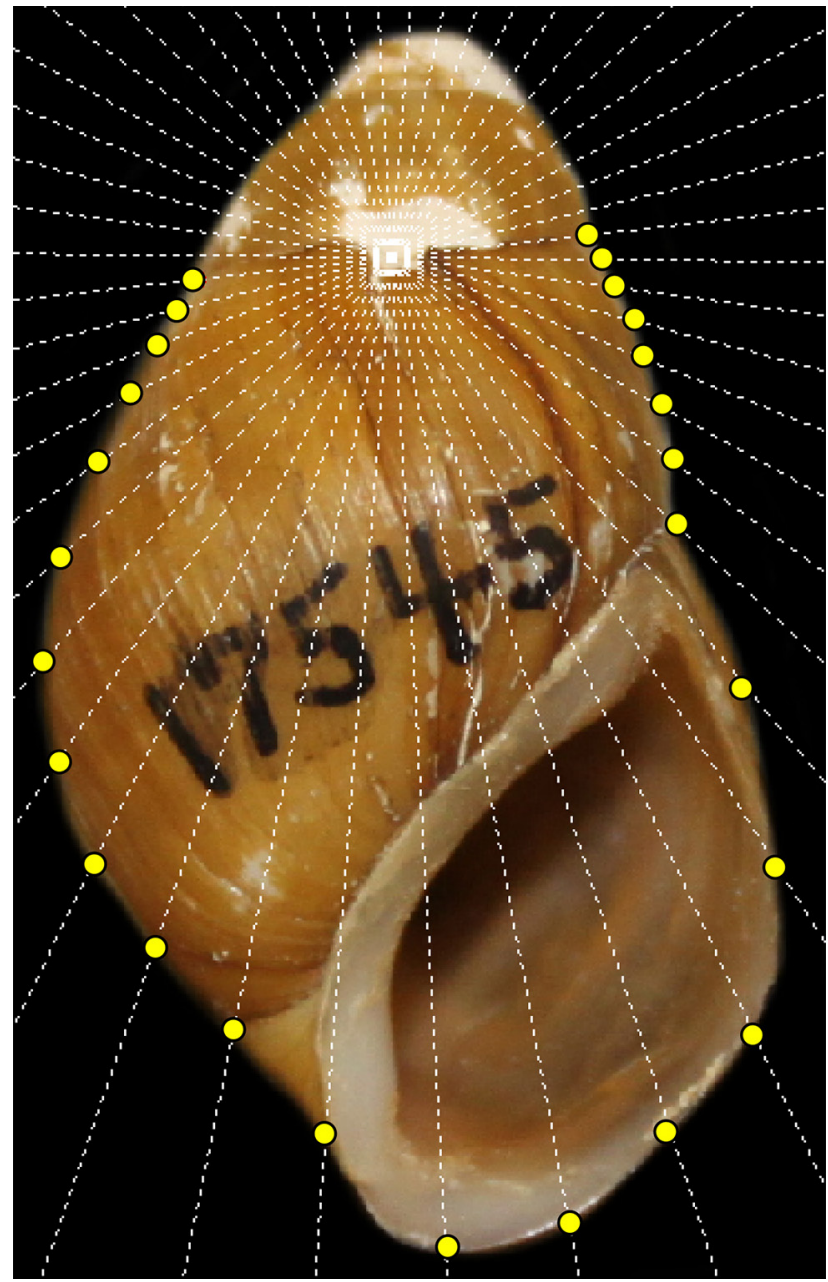

Fig. 3. Landmark positions overlaid on a L. geniculata shell image

To determine body whorl shape, we digitally photographed each snail and superimposed a radial fan of 50 evenly-spaced lines on the images (Fig. 3) using MakeFan8 (SHEETS 2014). We placed landmarks at one of the anchor points and where the lines crossed the body whorl using tpsDig2 (ROHLF 2017). We converted the x,y coordinates from 26 landmarks into shape variables using Procrustes superimposition (ROHLF \& SLICE 1990). From the Procrustes alignment, we also derived centroid size as a measure of overall shell size. We then determined the crushing resistance of each shell, measured as the force required to punch a conical tip through the body whorl. We employed a Mark-10 series 5 force gauge mounted on an ESM303 motorised test stand (Mark10, Copiague, New York) to determine the force to the nearest $0.1 \mathrm{~N}$. Each shell was positioned aperture down on a metal plate, and the tip was allowed to punch through the shell; force data were recorded every $0.1 \mathrm{~s}$ until first failure of the whorl. Care was taken to avoid applying force at any point where the shell was sculptured.
Table 2. Actual and predicted mean discharge volume (cfs) for Duck River sites from 2010 to 2016. Labelled stations were used in the regression to predict discharge at the remaining sites. Station numbers refer to U. S. Geological Survey sites

\begin{tabular}{ccc}
\hline River mile & Station & Discharge \\
\hline 15.9 & & 4012.11 \\
25 & 03603000 above Hurricane Mills & 3930.14 \\
32.2 & & 3756.85 \\
64.0 & & 3258.86 \\
70 & 03601990 Hwy 100 at Centerville & 3254.29 \\
98.0 & & 2726.42 \\
113.9 & & 2477.43 \\
122.3 & & 2345.88 \\
132 & 03599500 Columbia & 1904.86 \\
159.4 & & 1764.90 \\
179 & 03599240 above Milltown & 1545.71 \\
186.5 & & 1340.51 \\
192.5 & & 1246.55 \\
221 & 03597860 Shelbyville & 795.54 \\
221.3 & & 784.58 \\
222.0 & & 777.46 \\
235.7 & & 570.04 \\
242.5 & & 463.55 \\
265 & 03596000 below Manchester & 185.97 \\
269.4 & & 42.30 \\
\hline
\end{tabular}

Using the distribution maps in ETNIER \& STARNES (1984), we noted which fish occurring in the Duck River were known or potential molluscivores. We separated the river into three stretches (Fig. 2), based on morphotype occurrence (DAVIS 1974): the lower Duck (mouth upstream to Only, TN; approximate river miles 0-35); middle Duck (Only upstream to Normandy Dam; river miles 35-248); and upper Duck (above Normandy Dam; river mile 248+). We identified three different fish distribution patterns. River redhorse (Moxostoma carinatum (Cope, 1870)) and freshwater drum (Aplodinotus grunniens Rafinesque, 1819) are known from the lower and middle reaches, redear sunfish (Lepomis microlophus (Günther, 1859)) are known from the lower and upper reaches, and saddleback (Percina vigil (Hay, 1882)) and greenside (Etheostoma blennioides Rafinesque, 1819) darters are found in the lower or middle and upper reaches respectively.

All analyses were performed in R 3.4.2 (R CORE TEAM 2017); most utilised the geomorph (ADAMS \& OTÁROLA-CASTILLO 2013) package. We first tested for allometry in the shells using a Procrustes ANOVA with shell shape and log centroid size. We regressed shell mass and crushing resistance against log centroid size, and all three measures against river discharge, looking for significant trends in our data. We then explored the effects of discharge, size, and predation on shell shape using a Procrustes ANOVA (GOODALL 1991). We used log centroid size in the 
ANOVA, and coded the presence and absence of predators in the three defined reaches of the Duck River as factors. Finally, we analysed the crushing resistance of each shell as a function of shell size, mass, and shape. We log-transformed crushing resistance prior to analysis, and again used log centroid size in a
Procrustes ANOVA. For both analyses, we used type II sum of squares to remove the order dependence of our independent variables, and calculated the proportion of variance explained by each factor $\left(\eta^{2}\right)$ from the results. Significance for each analysis was set at $\alpha<0.05$.

\section{RESULTS AND DISCUSSION}

Shells of Duck River L. geniculata exhibited significant allometry $(\mathrm{F}=2.904, \mathrm{df}=1,209, \mathrm{p}<0.05)$; smaller shells had narrower body whorls than larger shells (Fig. 4). Larger shells had greater mass $\left(\mathrm{R}^{2}=\right.$ $0.057, \mathrm{p}<0.05)$ but there was no relationship between size and crushing force $(p=0.425)$. Shell mass $\left(\mathrm{R}^{2}=0.378, \mathrm{p}<0.05\right)$ and crushing force $\left(\mathrm{R}^{2}=\right.$ $0.295, \mathrm{p}<0.05)$ both showed positive relationships with river discharge, but no significant association was seen between size and discharge $(p=0.892)$. The Procrustes ANOVA relating shell shape to size $(\mathrm{F}=2.542)$, discharge $(\mathrm{F}=15.4682$; Fig. 5$)$, and predation (drum/redhorse $\mathrm{F}=8.4944$; greenside/ saddleback darters $F=5.143$; Fig. 6) showed signifi-
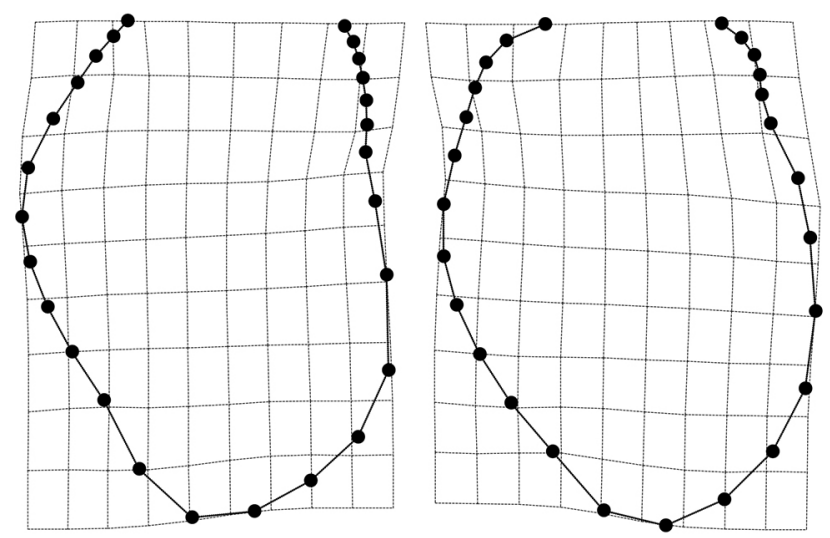

Fig. 4. Thin-plate spline deformations showing shape reconstructions by log centroid size (allometry; smallest at left, largest at right) in Duck River L. geniculata
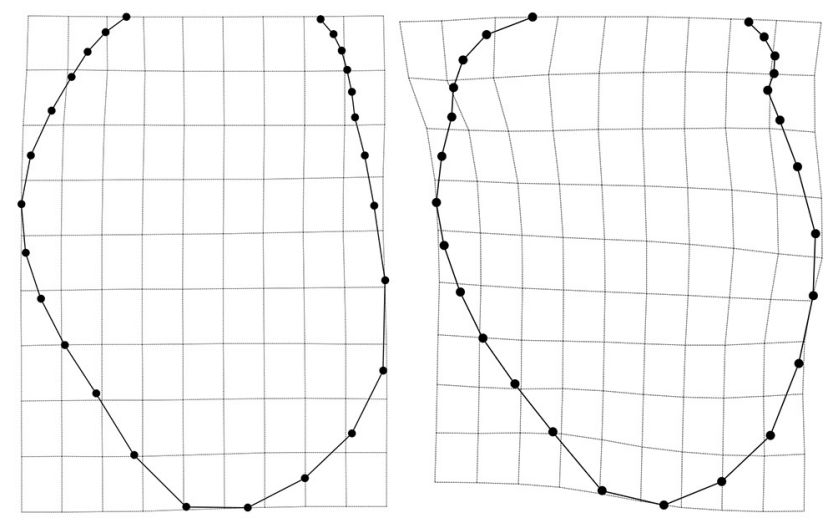

Fig. 5. Thin-plate spline deformations showing shape reconstructions by discharge (least at left, most at right) in Duck River L. geniculata cant associations ( $\mathrm{df}=1,1,1,1,1,294, \mathrm{p}<0.05)$ of shape and independent variables except for presence/ absence of redear sunfish $(p=0.316)$. Discharge explained the greatest percentage of total variance $\left(\eta^{2}\right.$ $=0.044)$ followed by drum/redhorse (0.024), darters (0.015) and size (0.007). The Procrustes ANOVA ( $\mathrm{df}$ $=48,1,1,249)$ for crushing force indicated significant effects $(\mathrm{p}<0.05)$ of shell shape $(\mathrm{F}=2.007)$ and mass $(\mathrm{F}=43.851)$, but not of shell size $(\mathrm{p}=0.328)$. Shell mass $\left(\eta^{2}=0.208\right)$ accounted for more of the total variance than shell shape (0.094).

Understanding mollusc shell variation is of interest because it is relatively consistent across freshwater molluscs and results from the interaction of genetic and environmental factors (DEWITT 1996,
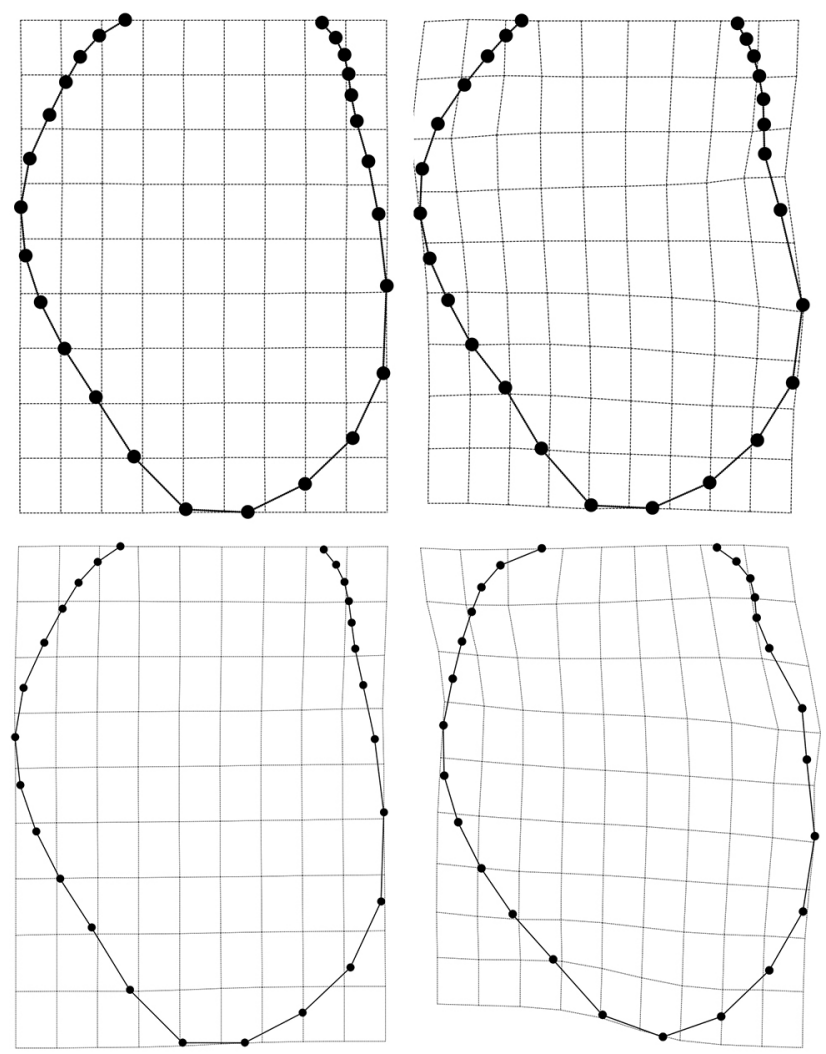

Fig. 6. Thin-plate spline deformations showing shape reconstructions by predator presence/absence in Duck River L. geniculata. Top, presence (left) and absence (right) of river redhorse and freshwater drum. Bottom, presence of either greenside (left) or saddleback (right) darters 
FALCONER \& MACKAY 1996, COVICH 2010). Riverine bivalve species show increased size (ZAJĄC et al. 2018) and shell obesity and sculpture downstream relative to upstream (HORNBACH et al. 2010), anecdotally referred to as ORTMANN's (1920) law of river position but described by earlier authors (SELL 1908, HAAS \& SCHWARZ 1913). Similar patterns are seen in freshwater snails due to predation (DEWITT 1998) and in pleurocerids overall (ADAMS 1900, 1915, GOODRICH 1937, ROSEWATER 1960, MINTON et al. 2011). In Duck River L. geniculata, we observed that smaller shells were narrower than larger shells, and that more globose shells were associated with greater discharge volumes and the presence of freshwater drum, river redhorse, and saddleback darter. Our allometric trend was opposite of that seen by MiNTON et al. (2008), who suggested smaller shells were more globose. We feel this discrepancy may be due to sample size; we used 300 shells compared to over 1,100 shells used previously, and MINTON et al. (2008) used more shells of each morphotype, including many that were intermediate between forms. We feel that, taken together, the data suggest that allometry across different morphotypes may not be meaningful relative to analysing each form separately.

Our data supported MINTON et al.'s (2008) finding that shells of $L$. geniculata are more globose downstream relative to upstream, whether due to discharge as we showed, or by other correlated factors associated with the unidirectional riverine environment. Wider shells have the potential for larger apertures, giving the snails larger pedal areas for adhering to the substrate (MCMAHON 2003, ETTER 2007). Narrower shells occurred upstream in lower flow reaches, consistent with results seen in riverine (DUNITHAN et al. 2012) and lacustrine (CAZENAVE \& ZANATTA 2016) snail species. Narrow shells allow snails to retract farther inwards (EDGELL \& MIYASHITA 2009) in an effort to avoid aperture-entry predators such as crayfish, and may be hydrodynamically favoured in middle and upper river reaches. Additionally, shell shape, mass, and crushing force in L. geniculata increased with discharge rate. Increased shell mass correlates with shell thickness, and both are defences against shell-crushing predators (SEELY 1986, LOWELL et al. 1994, EDGELL \& NEUfELD 2008) which tend to occupy deeper and faster-flowing river reaches. Resistance to crushing in L. geniculata was significantly correlated to shell mass and shape, but not size. Shells with increased globosity and robustness (e.g. shells that were heavy for their size) required more force to crush than nar- rower, less massive shells. The more spherical an object, the more force is required to crush it (NRC 1927). Increased globosity and robustness may protect shells dislodged in fast current from tumbling damage. Globose L. geniculata, specifically those with the geniculata morphotype, also tend to be sculptured as well (Minton et al. 2008). The combination of globosity, robustness, and shell ornamentation can increase handling time in shell-crushing predators and may serve as a deterrent to predation.

Despite shell variation being well documented in pleurocerids, only one author has tested whether it may be an example of adaptive plasticity in the family. KRIST (2002) showed that Elimia livescens grown in the presence of a crayfish effluent predator cue developed narrower body whorls, and that snails with narrow-bodied shells were less frequently eaten by crayfish than wider-bodied snails. Adaptive plasticity generally has not been documented thoroughly (SCHEINER 1993, GOTTHARD \& NYLIN 1995) because proof of any adaptive value requires measures of fitness in multiple varying environments (DEWITT \& SCHEINER 2004). In L. geniculata, differences in size, shape, and crushing resistance suggest that shell variation among morphotypes may be adaptive since certain forms dominate populations along the river; these forms possess traits that are assumed to increase fitness because they have in other taxa. However, there is no direct evidence suggesting alternate forms would perform worse at the same locations along the river, nor that any fitness differences would exist. Data on whether selection is acting on genotypes for plasticity versus some other developmental or behavioural trait is also lacking, and correlations of fitness and heritability to form and function may vary (CHAVES-CAMPOS et al. 2012). Future research focused on testing fitness of the various forms of $L$. geniculata in different environments can directly address the evolution, plasticity, and adaptive nature of shell variation in Lithasia.

\section{ACKNOWLEDGEMENTS}

We thank DAVID NEELY for assistance with fish dietary information, and the Ohio State Museum of Zoology for providing us with shells to crush. RM and $\mathrm{KCH}$ were supported in part by funds from the UHCL College of Science and Engineering and Texas Academy of Science. RF and CB were partially supported by a University System of Georgia STEM Initiative II grant. 


\section{REFERENCES}

ADAms C. C. 1900. Variation in Io. Proc. Am. Assoc. Adv. Sci. 49: 208-225.

ADAMS C. C. 1915. The variations and ecological distribution of the snails of the genus Io. Mem. Natl. Acad. Sci. 12: 1-92. https://doi.org/10.5962/bhl.title.52022

ADAMS D. C., OTÁROLA-CASTILLO E. 2013. geomorph: an $\mathrm{R}$ package for the collection and analysis of geometric morphometric shape data. Methods Ecol. Evol. 4: 393-399. https://doi.org/10.1111/2041-210X.12035

AleXAnder J. E., COVICH A. P. 1991. Predation risk and avoidance behavior in two freshwater snails. Biol. Bull. 180: 387-393. https://doi.org/10.2307/1542339

APPLETON R. D., PALMER A. R. 1988. Water-borne stimuli released by predatory crabs and damaged prey induce more predator-resistant shells in a marine gastropod. P. Natl. Acad. Sci. USA 85: 4387-4391. https://doi. org/10.1073/pnas.85.12.4387

BERRIGAN D., SCHEINER S. M. 2004. Modeling the evolution of phenotypic plasticity. In: DEWITT T. J., SCHEINER S. M. (eds). Phenotypic Plasticity. Oxford University Press, New York, pp. 82-97.

BROWN K. M., QUINN J. F. 1988. The effect of wave action on growth in three species of intertidal gastropods. Oecologia 75: 420-425. https://doi.org/10.1007/ BF00376946

CAZENAVE K. R., ZANATTA D. T. 2016. Environmental drivers of shell shape in a freshwater gastropod from small and large lakes. Freshwater Sci. 35: 948-957. https:// doi.org/10.1086/686912

Chaves-Campos J., Coghill L. M., Garcia De LeON F. J., JOHNSON S. G. 2012. The effect of aquatic plant abundance on shell crushing resistance in a freshwater snail. PLoS ONE 7: e44374. https://doi.org/10.1371/journal. pone. 0044374

Covich A. P. 2010. Winning the biodiversity arms race among freshwater gastropods: competition and coexistence through shell variability and predator avoidance. Hydrobiologia 653: 191-215. https://doi.org/10.1007/ s10750-010-0354-0

DAVIS G. M. 1974. Report on the rare and endangered status of a selected number of freshwater Gastropoda from southeastern U.S.A. Unpublished report submitted to the United States Fish and Wildlife Service, United States Department of the Interior, Washington D. C.

DEWITT T. J. 1996. Functional tradeoffs and phenotypic plasticity in the freshwater snail Physa. Ph. D. thesis, Binghamton University, New York.

DEWITT T. J. 1998. Costs and limits of phenotypic plasticity: tests with predator-induced morphology and life-history in a freshwater snail. J. Evolution. Biol. 11: 465-480. https://doi.org/10.1046/j.1420-9101.1998.11040465.x

DeWiTt T. J., SCheINER S. M. 2004. Phenotypic plasticity. Oxford University Press, New York.

DeWitt T. J., Robinson B. W., Wilson D. S. 2000. Functional diversity among predators of a freshwater snail impose an adaptive tradeoff for shell morphology. Evol. Ecol. Res. 2: 129-148.
DILLON R. T. 1984. What shall I measure on my snails? Allozyme data and multivariate analysis used to reduce the non-genetic component of morphological variance in Goniobasis proxima. Malacologia 25: 503-511.

DiLlon R. T. 2000. The ecology of freshwater molluscs. Cambridge University Press, Cambridge. https://doi. org/10.1017/CBO9780511542008

Dunithan A., JACQUEMIN S., PYRON M. 2012. Morphology of Elimia livescens (Mollusca: Pleuroceridae) in Indiana, U.S.A. covaries with environmental variation. Am. Malacol. Bull. 30: 127-133. https://doi. org/10.4003/006.030.0110

DUSSART G. B. J. 1987. Effects of water flow on the detachment of some aquatic pulmonate gastropods. Am. Malacol. Bull. 5: 65-72.

Edgell T. C., MiYashita T. 2009. Shell shape and tissue withdrawal depth in 14 species of temperate intertidal snail. J. Mollus. Stud. 75: 235-240. https://doi. org/10.1093/mollus/eyp018

EdGell T. C., Neufeld C. J. 2008. Experimental evidence for latent developmental plasticity: intertidal whelks respond to a native but not an introduced predator. Biol. Lett. 4: 385-387. https://doi.org/10.1098/ rsbl.2008.0204

ETNIER D. A., STARnES W. C. 1984. The fishes of Tennessee. The University of Tennessee Press, Knoxville.

ETTER R. J. 1988. Physiological stress and color polymorphism in the intertidal snail Nucella lapillus. Evolution 42: 660-680. https://doi.org/10.1111/j.1558-5646.1988. tb02485.x

ETter R. J. 2007. Snails. In: DenNy M. W., GAines S. D. (eds). Encyclopedia of tidepools and rocky shores. University of California Press, Oakland, pp. 530-536.

FALCONER D. S., MACKAY T. F. 1996. Introduction to quantitative genetics, 4th edition. Longman Scientific and Technical, Essex.

GoodAll C. 1991. Procrustes methods in the statistical analysis of shape. J. Roy. Stat. Soc. B 53: 285-339.

GoODRICH C. 1937. Studies of the gastropod family Pleuroceridae - VI. Occas. Pap. Mus. Zool. 347: 1-12.

GotTHARD K., NYLIN S. 1995. Adaptive plasticity and plasticity as adaptation: a selective review of plasticity in animal morphology and life history. Oikos 74: 3-17. https://doi.org/10.2307/3545669

HAAS F., SCHWARZ E. 1913. Die Unioniden des Gebietes zwischen Mainz und deutschen Donau in tiergeographischer Hinsicht. Abh. Math.-Phys. Kl. K. Bayer. Akad. Wiss. 26: 1-34.

HAASE M. 2003. Clinal variation in shell morphology of the freshwater gastropod Potamopyrgus antipodarum along two hill-country streams in New Zealand. J. Roy. Soc. N. Z. 33: 549-560. https://doi.org/10.1080/0301422 3.2003.9517743

HORNBACH D. J., KURTH V. J., HOVE M. C. 2010. Variation in freshwater mussel shell sculpture and shape along a river gradient. Am. Midl. Nat. 164: 22-36. https://doi. org/10.1674/0003-0031-164.1.22 
HurYN A. D., DENNY M. W. 1997. A biomechanical hypothesis explaining upstream movements by the freshwater snail Elimia. Funct. Ecol. 11: 472-483. https:// doi.org/10.1046/j.1365-2435.1997.00116.x

JOHNSON P. D., BOGAN A. E., BROWN K. M., BURKHEAD N. M., Cordeiro J. R., Garner J. T., HaRTFIEld P. D., LEPITZKi D. A. W., MACKIE G. L., PIP E., TARPley T. A., Tiemann J. S., Whelan N. V., Strong E. E. 2013. Conservation status of freshwater gastropods of Canada and the United States. Fisheries 38: 247-282. https://doi.org/10.1080/03632415.2013.785396

Kistner E. J., DyBDAHL M. F. 2013. Adaptive responses and invasion: the role of plasticity and evolution in snail shell morphology. Ecol. Evol. 3: 424-436. https:// doi.org/10.1002/ece3.471

KRIST A. C. 2002. Crayfish induce a defensive shell shape in a freshwater snail. Invertebr. Zool. 121: 235-242. https://doi.org/10.1111/j.1744-7410.2002.tb00063.x

Lowell R. B., Fletcher C. R., Grahame J. W., Mill P. J. 1994. Ontogeny of shell morphology and shell strength of the marine snails Littorina obtusata and Littorina mariae: different defense strategies in a pair of sympatric, sibling species. J. Zool. 234: 149-164. https://doi. org/10.1111/j.1469-7998.1994.tb06062.x

MCMAHON R. F. 2003. Contributions of the Hong Kong malacological and marine workshops to the comparative and ecological physiology of intertidal invertebrates. In: MORTON B. (ed.). Perspectives on Marine Environment Change in Hong Kong and Southern China. Hong Kong University Press, Hong Kong, pp. 479-515.

MinTON R. L., LydEARD C. 2003. Phylogeny, taxonomy, genetics and global heritage ranks of an imperiled, freshwater snail genus Lithasia (Pleuroceridae). Mol. Ecol. 12: 75-87. https://doi.org/10.1046/j.1365294X.2003.01719.X

Minton R. L., Lewis E. M., Netherland B., Hayes D. M. 2011. Large differences over small distances: plasticity in the shells of Elimia potosiensis (Gastropoda: Pleuroceridae). Int. J. Biol. 3: 23-32.

Minton R. L., Norwood A. P., HAYES D. M. 2008. Quantifying phenotypic gradients in freshwater snails: a case study in Lithasia (Gastropoda: Pleuroceridae). Hydrobiologia 605: 173-182. https://doi.org/10.1007/ s10750-008-9332-1

NRC (NATIONAL RESEARCH COUNCIL) 1927. International Critical Tables of Numerical Data, Physics, Chemistry, and Technology. McGraw-Hill, New York.

ORTMANN A. E. 1920. Correlation of shape and station in freshwater mussels (naiades). Proc. Am. Phil. Soc. 59:269-312.

OsenberG C. W., MitTelbach G. G. 1989. Effects of body size on the predator-prey interaction between pumpkinseed sunfish and gastropods. Ecol. Mon. 59: 405432. https://doi.org/10.2307/1943074

R CORE TEAM 2017. R: A language and environment for statistical computing. R Foundation for Statistical Computing, Vienna, Austria. Available at https:// www.R-project.org/.

RASSER M. W., COVICH A. P. 2014. Predation on freshwater snails in Miocene Lake Steinheim: a trigger for intrala- custrine evolution? Lethaia 47: 524-532. https://doi. org/10.1111/let.12078

ROHLF F. J. 2017. tpsDig2. Available at http://life.bio.sunysb.edu/morph/soft-dataacq.html.

ROHLF F. J., SLICE D. 1990. Extensions of the Procrustes method for the optimal superimposition of landmarks. Syst. Biol. 39:40-59. https://doi.org/10.2307/2992207

ROSEWATER J. 1960. Geographic variation of Pleurocera canaliculata (Mollusca: Prosobranchia) in the Ohio River basin. Ph. D. thesis, Harvard University, Cambridge.

SCHEINER S. M. 1993. Genetics and evolution of phenotypic plasticity. Annu. Rev. Ecol. Evol. S. 24:35-68. https:// doi.org/10.1146/annurev.es.24.110193.000343

SEELY R. H. 1986. Intense natural selection caused a rapid morphological transition in a living marine snail. P. Natl. Acad. Sci. USA 83: 6897-6901. https://doi. org/10.1073/pnas.83.18.6897

SELL H. 1908. Biologische Beobachtungen an Najades. Arch. Hydrobiol. Plankton. 1908: 179-188.

SHEETS H. 2014. MakeFan8. Available at http://www3.canisius.edu/ sheets/IMP\%208.htm.

STEARNS S. C. 1989. Trade-offs in life-history evolution. Funct. Ecol. 3: 259-268. https://doi.org/10.2307/2389364

STEIN C. B., STANSBERY D. H. 1984. A systematic study of the morphological forms of ellipstomid snails in the Duck River, Tennessee, using electrophoretic analysis. Unpublished report submitted to the United States Fish and Wildlife Service, United States Department of the Interior, Washington D. C.

TOLlRian R., HARVEll C. D. 1999. The ecology and evolution of inducible defenses. Princeton University Press, Princeton.

TRUSSELl G. C. 2000. Phenotypic clines, plasticity, and morphological trade-offs in an intertidal snail. Evolution 54: 151-166. https://doi.org/10.1111/j.0014-3820.2000. tb00016.x

TRYON G. W. 1873. Land and freshwater shells of North America. Part IV. Strepomatidae. Smithsonian Misc. Coll. 16: 1-435.

USGS (UNITED STATES GEOLOGICAL SURVEY) 2017. Water resources. Available at http://water.usgs.gov.

VANNOte R. L., Minshall G. W., Cummins K. W., Sedell J. R., Cushing C. E. 1990. The river continuum concept. Can. J. Fish. Aquat. Sci. 37: 130-137. https://doi. org/10.1139/f80-017

WHELAN N. V., JOHNSON P. D., HARRIS P. M. 2012. Presence or absence of carinae in closely related populations of Leptoxis ampla (Anthony, 1855) (Gastropoda: Cerithioidea: Pleuroceridae) is not the result of ecophenotypic plasticity. J. Mollus. Stud. 78: 231-233. https:// doi.org/10.1093/mollus/eys005

ZAJAC K., ZAJAC T., ĆMIEL A. 2018. What can we infer from the shell dimensions of the thick-shelled river mussel Unio crassus? Hydrobiologia 810: 415-431. https://doi. org/10.1007/s10750-017-3098-2

Received: December 13th, 2017

Revised: April 6th, 2018

Accepted: April 23rd, 2018

Published on-line: June 5th, 2018 